\title{
Critically ill patients with icu-acquired weakness show reduced density of myosin in electron microscope early after onset of critical illness
}

\author{
T Rathke*, T Wollersheim, M Krebs, M Schülke, S Weber-Carstens
}

From ESICM LIVES 2015

Berlin, Germany. 3-7 October 2015

\section{Introduction}

Recently we showed increased expression of atrophy genes MuRF-1 and Atrogin-1 during early course of critical illness resulting in $\mathrm{MyHC}$ loss and finally the clinical presentation of ICU-acquired weakness. Appropriate studies of systematic electron microscope investigations from this early time in critical illness do not exist yet.

\section{Objectives}

To investigate muscle ultrastructure with electron microscopy within the time course of critical illness.

\section{Methods}

Controlled, prospective, monocentric observational study. We included 30 mechanically ventilated, critically ill patients (SOFA score $\geq 8$ at 3 within 5 days after ICU admission). Two open muscle biopsies ( $M$. vastus lateralis) were obtained at median day 5 and 16. Electron microscope studies were performed and counting of myosin filaments in cross section was done using Image J Software. Reference values were taken from Riley et al.. Muscle strength was assessed using Medical Research Council (MRC)-Scale when patients were alert later in ICU course. Non-parametric tests were performed. Ethic vote (Charité EA2/061/06).

\section{Results}

We see a significant reduction of myosin filament to almost half the normal density already in the first biopsy: $\mathrm{n} / \mu \mathrm{m}^{2}$ (mean/SD): 577/193 vs.1054/71. There is no significant ongoing decrease of myosin filament later according to second biopsy - $\mathrm{n} / \mu \mathrm{m}^{2}(\mathrm{mean} / \mathrm{SD}): 416 / 172$. We found a significant correlation of myosin filament density and MRC-Scale for the first biopsy, yet not for the second biopsy.

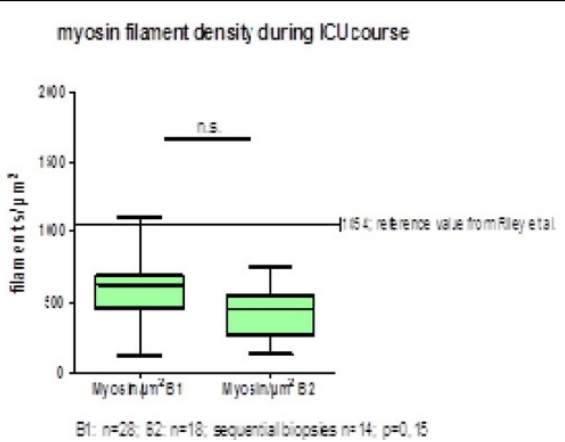

Corelation of MRC \& myosin filament density of first biopsy

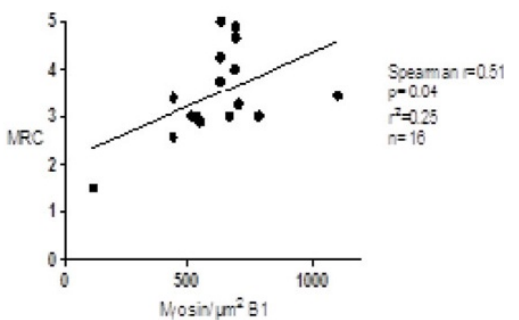

Figure 1 


\section{Conclusions}

Electron microscopy reveals a serious reduction of myosin filament density very rapidly after onset of critical illness. However, during course of critical illness the further reduction of myosin filament density is of minor degree. The early myosin filament loss determines development of ICU-acquired weakness later during ICU stay, when patients emerge from sedation.

\section{Grant Acknowledgment}

Funded by DFG, KFO 192, WE 4386/1-2.

Published: 1 October 2015

\section{References}

1. Riley DA, et al: Disproportionate loss of thin filaments in human soleus muscle after 17-day bed rest. Muscle Nerve 1998, 21:1280-1289.

2. Wollersheim T, et al: Dynamics of myosin degradation in intensive care unit-acquired weakness during severe critical illness. Intensive Care Med 2014, 40:528-538.

doi:10.1186/2197-425X-3-S1-A44

Cite this article as: Rathke et al:: Critically ill patients with icu-acquired weakness show reduced density of myosin in electron microscope early after onset of critical illness. Intensive Care Medicine Experimental 2015 3(Suppl 1):A44.

\section{Submit your manuscript to a SpringerOpen ${ }^{\mathcal{O}}$ journal and benefit from:}

- Convenient online submission

- Rigorous peer review

- Immediate publication on acceptance

- Open access: articles freely available online

- High visibility within the field

- Retaining the copyright to your article 